Discussion Paper No. 13-069

\title{
Estimating Consumer Damages in Cartel Cases
}

Ulrich Laitenberger and Florian Smuda

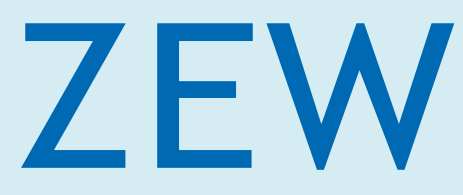

Zentrum für Europäische Wirtschaftsforschung $\mathrm{GmbH}$ Centre for European Economic Research 
Discussion Paper No. 13-069

\title{
Estimating Consumer Damages in Cartel Cases
}

\author{
Ulrich Laitenberger and Florian Smuda
}

Download this ZEW Discussion Paper from our ftp server:

http://ftp.zew.de/pub/zew-docs/dp/dp13069.pdf

Die Discussion Papers dienen einer möglichst schnellen Verbreitung von neueren Forschungsarbeiten des ZEW. Die Beiträge liegen in alleiniger Verantwortung der Autoren und stellen nicht notwendigerweise die Meinung des ZEW dar.

Discussion Papers are intended to make results of ZEW research promptly available to other economists in order to encourage discussion and suggestions for revisions. The authors are solely responsible for the contents which do not necessarily represent the opinion of the ZEW. 


\section{Non-technical summary}

During recent years the question of legal standing of consumer associations in the course of private cartel damage claims has increasingly attracted attention within the European Commission (EC). The European Consumer Consultative Group (ECCG), a sub division of the EC for end consumer interests, adopted an opinion on private damages actions in November 2010. The ECCG states that "innovative and practical solutions to the calculation of damages are needed to replace the often impossible task of calculating the exact loss."

Against this background, we show in this article how final consumer damages can be empirically quantified. In particular, using a consumer panel dataset with 35.000 transactions we estimate the damage suffered by German consumers due to the European detergent cartel. The cartel lasted from January 2002 until March 2005 and covered the markets of eight European countries. The three largest producers of heavy laundry detergents, who collect around two thirds of the sales and volume in the German detergent market, were involved in this cartel.

Our estimations suggest average overcharges between 6.7 and 6.9 percent and an overall consumer damage of about 13.2 million Euro over the period from July 2004 until March 2005. Under the assumptions that the cartel-induced share on turnover is representative for the entire cartel period and all affected markets, the overall consumer damage even accounts for about 315 million Euro. Our results further suggest that the retailers reacted to the price increases of the cartel firms via price increases for their own detergent products, resulting in significant umbrella effects. We quantify the damage due to this umbrella pricing to a total of 7.34 million Euro. Our findings are important for cartel damage estimations in general and for the quantification of consumer harm by consumer associations in particular. 


\section{Das Wichtigste in Kürze}

In den vergangenen Jahren wurde der Frage nach der Klagebefugnis von Verbraucherverbänden im Rahmen privater Schadensersatzforderungen bei Kartellfällen zunehmend Aufmerksamkeit von Seiten der Europäischen Kommission (EK) eingeräumt. Die Europäische Beratende Verbrauchergruppe (ECCG), ein von der EK eingerichtetes Konsortium europäischer und nationaler Verbraucherorganisationen, veröffentlichte im November 2010 eine Stellungnahme zu privaten Schadensersatzerklagen. Darin weist die ECCG darauf hin, dass "innovative und praktische Lösungen zur Berechnung von Schäden benötigt werden, um die oftmals unmögliche Aufgabe der Berechnung des exakten Schadens zu lösen".

Vor diesem Hintergrund zeigen wir in dem vorliegendem Papier, wie der von Endkonsumenten erlittene Kartellschaden empirisch ermittelt werden kann. Unter Verwendung eines KonsumentenpanelDatensatzes bestehend aus 35.000 Transaktionen schätzen wir den von deutschen Konsumenten erlittenen monetären Schaden infolge des Europäischen Waschmittelkartells. Das Kartell existierte zwischen Januar 2002 und März 2005 und war in insgesamt acht europäischen Ländern aktiv. Die drei größten Waschmittelhersteller, welche zusammen etwa zwei Drittel des Umsatzes und Absatzes im deutschen Waschmittelmarkt vereinnahmten, waren an dem Kartell beteiligt.

Unsere Schätzungen ergeben durchschnittliche kartellbedingte Preisaufschläge zwischen 6.7 und 6.9 Prozent und einen Konsumentenschaden von insgesamt 13.2 Millionen Euro für den Zeitraum Juli 2004 bis März 2005. Unter der Annahme, dass der kartellbedingte Anteil am Umsatz repräsentativ für den gesamten Kartellzeitraum und alle betroffenen Märkte ist, ergibt sich ein Gesamtschaden von 315 Millionen Euro. Unsere Ergebnisse deuten zudem darauf hin, dass die Einzelhändler auf die Preiserhöhungen der Kartellfirmen mittels Preiserhöhungen für ihre selbst produzierten Waschmittelprodukte reagiert haben und es dadurch zu signifikanten Preisschirmeffekten kam. Die dadurch verursachten Konsumentenschäden belaufen sich auf insgesamt 7.34 Millionen Euro. Unsere Ergebnisse liefern wichtige Erkenntnisse für Schadensschätzungen im Allgemeinen und für die Quantifizierung von Konsumentenschäden durch Verbraucherverbände im Speziellen. 


\title{
Estimating Consumer Damages in Cartel Cases
}

\author{
Ulrich Laitenberger, Florian Smuda ${ }^{\dagger}$
}

September 16, 2013

\begin{abstract}
We use consumer panel data to calculate the damage suffered by German consumers due to a detergent cartel that was active between 2002 and 2005 in eight European countries. Applying before-and-after and difference-in-differences estimations we find average overcharges between 6.7 and 6.9 percent and an overall consumer damage of about 13.2 million Euro over the period from July 2004 until March 2005. Under the assumptions that the cartel-induced share on turnover is representative for the entire cartel period and all affected markets, the overall consumer damage would even sum up to about 315 million Euro. Our results further suggest that the retailers reacted to the price increases of the cartel firms via price increases for their own detergent products, resulting in significant umbrella effects. We quantify the damage due to this umbrella pricing to a total of about 7.34 million Euro. With respect to the discussion whether special procedures for bringing collective actions should be available in the EU, our results are important to the extent that we show how consumer associations can use consumer panel data in order to claim damages before national courts and thereby actively fulfill their mandate of consumer protection.
\end{abstract}

Keywords: cartels, damages, consumers, detergents, private damage claims

JEL-codes: L13, L41, L44

*ZEW Centre for European Economic Research, Competition and Regulation Research Group and MaCCI Mannheim Centre for Competition and Innovation, Address: L7,1, 68161 Mannheim, Germany; E-mail: laitenberger@zew.de; Internet: www.zew.de; KU Leuven, Department of Managerial Economics, Strategy and Innovation, Naamsestraat 69, 3000 Leuven, Belgium.

${ }^{\dagger}$ ZEW Centre for European Economic Research, Competition and Regulation Research Group and MaCCI Mannheim Centre for Competition and Innovation, Address: L7,1, 68161 Mannheim, Germany; E-mail: smuda@zew.de; Internet: www.zew.de; University of Hohenheim, Institute of Economics, 70593 Stuttgart, Germany.

We are indebted to Kai Hüschelrath, Sven Heim, Francois Laisney, Gerhard Wagenhals and participants at the CISS 2012, EARIE 2013 and the CLEEN Workshop 2013, in particular Marteen Pieter Schinkel and Frode Steen, for valuable comments. We thank Bastian Sattelberger and Anne Zirngiebl for excellent research assistance. 


\section{Introduction}

While cartel damages of purchasers are already widely discussed in both academia and practice, consumer harm has only played a minor role in the context of cartel damages claims so far. ${ }^{1}$ This is for obvious reasons. The damage suffered by an individual consumer regularly falls below the legal expenses needed to receive a compensation. Furthermore, in contrast to firms final consumers are not obliged to keep receipts and are therefore often neither able to prove the fact that they bought the cartel product during the collusive period nor at which price. This is especially the case when considering groceries, where several cartels have recently been discovered. ${ }^{2}$ Last but not least, current European competition law does not favor the exercise of class-action lawsuits which would allow to effectively bundle the individual claims of final consumers and could (at least) partially overcome some obstacles.

Despite these hurdles, during recent years the question of legal standing of consumer associations in the course of private damage claims has increasingly attracted attention within the European Commission (EC). ${ }^{3}$ The "European Consumer Consultative Group" (ECCG), a sub division of the EC for end consumer interests, adopted an opinion on private damages actions in November 2010. It contains several proposals to improve private damages actions by consumer associations, amongst others (i) the facilitation of the burden of proof for consumer organizations and (ii) the assurance of redress for all consumers. In this context, the ECCG states that "innovative and practical solutions to the calculation of damages are needed to replace the often impossible task of calculating the exact loss." ${ }^{4}$ In particular, the ECCG argues that "it should be possible to rely on a reasonable estimate of an overcharge." 5

Against this background, we contribute to the current discussion by showing how final consumer damages can be quantified empirically. In particular, we estimate the damage suffered by German consumers due to the European detergent cartel. The cartel lasted from January 2002 until March 2005 and covered the markets of eight European countries. The three largest producers of heavy laundry detergents, who collect around two thirds of the sales and volume in Germany, were involved in this cartel. ${ }^{6}$ For the estimation, we use survey data of consumer transactions from The Nielsen Company. The dataset covers the last nine months of the cartel period and additionally 15

\footnotetext{
${ }^{1}$ One example is the French mobile phone cartel, in which the French consumer association "UFC Que Choisir" attracted around 12.500 consumers for an (in the end unsuccessful) opt-in damage claim. In the UK, the consumer association "Which!" also claimed damages against JJB Sports, however, only 130 consumers joined the claim. See Bien, 2013.

${ }^{2}$ Remarkable examples are the three German cases coffee roasters (2010), chocolate manufacturers (2012) and most recently flour (2013).

${ }^{3}$ The starting point was the EC green paper (EC, 2005) on damage claims, in which one section explicitly deals with the defense of consumer interests and raises the question whether special procedures for bringing collective actions and protecting consumer interests should be available. This view was emphasized in the subsequent white paper (EC, 2008), in which the EC states "that there is a clear need for mechanisms allowing aggregation of the individual claims of victims of antitrust infringements".

${ }^{4}$ See European consumer consultative group (2010) - Opinion on private damages actions, section 2.3 .

${ }^{5} \mathrm{Id}$.

${ }^{6}$ See, e.g., Commission decision of 13.04.2011, Case Comp/39579 - Consumer detergents.
} 
months after the breakdown of the cartel, which we use as competitive counterfactual benchmark.

We find an overall consumer damage of about 13.2 million Euro over the period from July 2004 until March 2005. Under the assumptions that the cartel-induced share on turnover is representative for the entire cartel period and all affected markets, the overall consumer damage even accounts for about 315 million Euro. This might still be a conservative estimate, as especially in the beginning of the cartel, prices could have been substantially higher and after cartel breakdown prices in general do not immediately adjust to the competitive level again.

The article is organized as follows. The subsequent section reviews the theoretical background of cartel damages and describes the potential harm that could emerge on the final consumer stage. Section 3 summarizes the cartel case under scrutiny and gives a description of the data set. Section 4 then describes our estimation approach and the calculation of the overall damage of German consumers. The article concludes with a summary of the main results and a discussion of policy implications in Section 5.

\section{Related literature}

The quantification of cartel damages is usually not straightforward. Especially when considering multi-layer markets in which one product is used as input in the production process of the adjacent stage, it is demanding to examine and allocate the various effects that percolate through the upand downstream layers after cartel formation. In general, the emergence of a cartel at some stage of such a supply chain leads to a higher price and less output in comparison to the prior competitive situation. That is, purchasers are confronted with higher input costs and may react to this change via own price increases, leading to further passing-on effects in the downstream layers. These price increases are generally accompanied by demand restrictions ("output effects") that detract firm specific profits. ${ }^{7}$ If one were to estimate the overall harm of cartelization all these effects must be taken into account. ${ }^{8}$

Within such a multi-layer market final consumers take a special position as they can not pass on the price increase they suffer. Thus, they can either accept the loss in consumer welfare or change their buying behavior and buy cheaper substitutes. However, those substitutes may itself be overpriced due to possible umbrella effects, implying that consumers are particularly in need of protection towards antitrust infringements.

\footnotetext{
${ }^{7}$ See Van Dijk and Verboven (2008) for a more detailed description of the different effects.

${ }^{8}$ More precisely, one would further have to include the damages of cartel suppliers and potential purchasers as well. Cartel suppliers might be damaged due to output restrictions, because less inputs are needed by the cartelists to produce the lower output. This may similarly lead to passing-on effects and price changes in the upstream layers. For an in-depth analysis, see Bueren and Smuda (2013). Potential purchasers might be damaged if they bought substitutes from non-colluding firms but would have bought the cartel product if prices had been constant. Thus, the overcharge suffered by them equals the difference between the price of the substitute and the but-for price of the cartel product.
} 
Han et al. (2008) theoretically show that the loss in consumer surplus is composed of two parts, the overcharge effect that equals the price increase of the product from the adjacent layer above multiplied by the quantity purchased, and the output effect which reflects foregone consumer purchases due to the higher price. They further analyze the impact of the level of competition at one layer on the magnitude of the passing-on effect as well as the size of the consumer damage relative to the direct purchaser overcharge. If perfect competition exists on each downstream layer, the incidental price increase of cartelists is completely passed on to final customers. The overall damage suffered by them can then even be larger than the direct purchaser overcharge. Conversely, if there is substantial market power in the intermediate layers the direct purchaser overcharge overestimates consumer harm.

Boone and Mueller (2012) use a market model with three layers to analyze the distribution of overall harm in terms of lost profits and lost consumer welfare between cartel purchasers and final consumers for the cases of homogenous and heterogeneous products. They find that the consumer harm share (CHS) is negatively related to (i) the industry aggregate price-cost margin and (ii) the pass-through elasticity, which measures the percentage change in output price in response to a one percent increase in input costs. In addition, they show that the CHS is independent of the number of downstream firms that are directly affected by cartelization. ${ }^{9}$

In sum, economic theory shows that in vertically related markets final consumers might face substantial cartel damages even if several intermediate layers are interposed between cartel stage and final consumers. The size of the damage however depends on the number of intermediate layers and their corresponding levels of competition. The lower the number of intermediate layers and the higher the degree of competition, the higher the price overcharge for final consumers.

In our case we have two intermediate layers placed between cartelists and consumers: wholesalers and retailers. Since wholesalers and retailers are typically integrated, increases in costs due to higher cartel prices are directly passed on to the retailers. Furthermore, the degree of competition in the retailing market is considered to be high. ${ }^{10}$ Retailers therefore set prices based on the wholesale price increased by a margin, which is based on the costs of retailing. Thus, we believe that a substantial fraction of the cartel induced cost increase should have been passed on to finals consumers, suggesting remarkable damages.

\footnotetext{
${ }^{9}$ Additional literature is available on cartel damages and passing-on effects in vertically related markets such as Kosicki and Cahill (2006), Verboven and van Dijk (2009) and Basso and Ross (2010), however, their articles do not explicitly deal with final consumer damages but rather focus on direct (indirect) purchasers.

${ }^{10}$ The ongoing German sector inquiry did not reveal any competition problems until now.
} 


\section{Description of the cartel case and the dataset}

\subsection{The European washing powder cartel}

Procter \& Gamble (Ariel and Lenor brands), Unilever (Coral brands) and Henkel (Persil brands) are the leading producers of washing powder in Europe. According to the EC, these three firms engaged in a cartel from at least January 2002 until March 2005, which was aimed at stabilizing market positions and at coordinating prices in violation of EU and EEA antitrust rules (Article 101 of the EU treaty and Art. 53 of the EEA agreement). ${ }^{11}$ The agreement covered the markets in Belgium, France, Germany, Greece, Italy, Portugal, Spain and the Netherlands and concerned heavy-duty laundry detergent powders used in washing machines (HDD low suds powder). ${ }^{12}$ The cartel started when the companies implemented an initiative through their trade association to improve the environmental performance of detergent products (AISE initiative). ${ }^{13}$

After cartel breakdown in 2005 and three further years of silence Henkel applied for leniency at the EC in 2008 and revealed the anti-competitive practices. ${ }^{14}$ The EC carried out inspections in June 2008 and subsequently, Procter \& Gamble and Unilever also applied for leniency under the EU's Leniency Notice. ${ }^{15}$

On 13 April 2011, the EC fined Procter \& Gamble and Unilever a total of 315.2 million Euro. Henkel received full immunity in terms of a 100 percent fine reduction because it was the first to inform the EC. Procter \& Gamble and Unilever were granted leniency reductions of 50 and 25 percent, respectively. Moreover, they also benefited from a 10 percent reduction due to their agreement for a settlement procedure that allowed the EC to simplify and reduce the length of the investigation. ${ }^{16}$ Thus, the information about the workings of the cartel given in the decision document is comparatively rather scarce. The Commission does not give any information why the cartel ended.

According to the EC the three firms were involved in various anti-competitive practices that have been coordinated in the course of meetings during the AISE environmental initiative. Firstly, they agreed on indirect price increases, comprising that prices were not reduced when the product

\footnotetext{
${ }^{11}$ See EC press release IP/11/473, 13/04/2011.

${ }^{12}$ See Commission decision of 13.04.2011, Case Comp/39579 - Consumer detergents, paragraph 15.

${ }^{13}$ The AISE environmental initiative is a voluntary initiative across different countries of the EEA. It targets amongst others on taking into account environmental considerations in the design of laundry detergent products and packages. The AISE's "Code of good Environmental Practices" specifies concrete goals in this regard, e.g. a 10 percent reduction per capita packaging material tonnage consumption.

${ }^{14}$ It is worth noting that in December 2011 the French competition authority has fined a similar cartel for pricefixing of washing powders, tablets and liquids in the French market between 1997 and 2004. Importantly, in addition to Colgate-Palmolive the participating firms were Henkel, Unilever and P\&G. The chronology of events suggests that the discovery of both cartels is closely related: In May 2008, Unilever applied for leniency at the French competition authority and only eight weeks later a leniency application by Henkel received the French regulator. After two further weeks Henkel then applied for leniency at the EC, Unilever however waited with its leniency application at the EC until October 2009. Hence, whereas Henkel received full immunity in the pan-European case and was fined by the French competition authority for its offense in the French market, Unilever got full immunity in the French case but was fined by the EC for its participation in the EU case.

${ }^{15}$ Supra n. 6.

${ }^{16} \mathrm{Id}$.
} 
volume or the number of wash loads per package was downsized, or when the products were compacted in terms of reduced weight. ${ }^{17}$ Furthermore, benefits and cost savings from reduced raw materials, packaging and transport costs were collectively refused to pass on to consumers. ${ }^{18}$ Secondly, the three cartelists agreed on a direct price increase at specific markets towards the end of 2004. These anti-competitive markups were realized via price leadership, in which the market leader pretended and implemented the excessive pricing pattern first and the other firms followed. ${ }^{19}$ Last but not least, Henkel, P\&G and Unilever collectively restricted their promotional activity by excluding specific types of promotions during the implementation of the different phases of the environmental initiative. ${ }^{20}$

In the course of this article we concentrate on the former anti-competitive practice. That is, we empirically analyze the indirect price increases that were realized during the cartel period. We then provide an estimate of the monetary damage suffered by consumers.

\subsection{Dataset}

We use a consumer panel dataset for the detergent category provided by The Nielsen Company. About 16.000 German customers report which products they bought on a daily basis. The dataset is at the product code level and includes characteristics like washing purpose, package type and size, detergent consistency, scent and concentration. For consumers, typical sociodemographic variables and a scaling factor for representativeness are given.

At first sight one might think that laundry detergent is a homogenous product. However, in total the dataset contains information on 1.145 different product codes. One has to distinguish between light-duty, heavy-duty, wool, cold and drape detergent; additional product characteristics are sensitive, color, unconcentrated and concentrated detergents. Regarding the consistency one can further differentiate between powder, liquid, tabs, wash nuts and gel. According to the EC the cartel only targeted at heavy-duty detergents in powder form. We therefore just use this distinct subcategory and omit the rest of the observations, which leaves us with approximately 35.000 observations that are attributed to 494 different product codes and 27 brands.

With respect to the classification of brands, we can generally distinguish between three groups of brands:

1. Cartel brands: Products of Henkel, Procter \& Gamble and Unilever

2. Competitive private brands by the retailers: e.g. Tandil from Aldi

3. Competitive manufacturer brands

\footnotetext{
${ }^{17}$ Supra n. 6, paragraph 25 .

${ }^{18}$ Id.

${ }^{19} \mathrm{Id}$.

${ }^{20}$ Id.
} 
As it is possible that both retailer and competitive manufacturer respond to price increases by the cartel via price changes of their own detergent products, we apply the (before-and-after) overcharge estimation separately to all three groups of brands. This additionally allows us the identification of a possible reference (brand-) category, which we can use for difference-in-differences estimations.

Another aspect that should be discussed is the level of data aggregation in the course of damage estimations. We use data on a highly disaggregated level in terms of single purchase acts of the observed consumers. This has mainly two reasons. Firstly, the product is highly differentiated and the various product characteristics of washing powder lead to price differences between product categories. When using aggregated prices and analyzing their changes, one can not distinguish between substitution effects and price changes on the product level. Secondly, in aggregated figures information on the numerous discounts that consumers obtain due to promotional activities are lost, which can bias the estimation. We therefore use single purchase acts as observation unit and do not further aggregate our data on a weekly or monthly basis.

The observed time period is from July 2004 until June 2006. Following the decision of the EC, we define March 2005 as the end of the cartel. ${ }^{21}$ Thus, the dataset covers the last nine months of the cartel period and additionally 15 months of the post-cartel period.

\subsection{Descriptive statistics}

Table 1 displays the descriptive statistics of the data set. ${ }^{22} 58$ percent of the purchase acts concern cartelfirm products and 39 percent of the observations refer to retailer brands. By contrast, manufacturer brand products contribute 3 percent of the data.

Table 1: Descriptive statistics

\begin{tabular}{lcc|lcc}
\hline Variable & Mean & \multicolumn{1}{c}{ Std. dev. } & Variable & Mean & Std. dev. \\
\hline \hline Price/kg & 1.98 & 0.78 & Concentrated & 0.62 & 0.49 \\
Cartel Brands & 0.58 & 0.49 & Color & 0.34 & 0.47 \\
Retailer Brands & 0.39 & 0.49 & Sensitive & 0.03 & 0.18 \\
Manufacturer Brands & 0.03 & 0.17 & Packaging: Box & 0.33 & 0.47 \\
Cartel Brands (CP) & 0.19 & 0.39 & Packaging: Bag & 0.54 & 0.50 \\
Retailer Brands (CP) & 0.12 & 0.32 & Packaging: Carry pack & 0.13 & 0.33 \\
Manufacturer Brands (CP) & 0.01 & 0.10 & Package size & 2.97 & 2.30 \\
Promotion & 0.29 & 0.45 & Package size(sq) & 14.07 & 23.06 \\
Gimmick & 0.07 & 0.26 & & & \\
\hline
\end{tabular}

$n=35.225$

\footnotetext{
${ }^{21}$ It is worth noting that after a cartel breakdown prices might not immediately return to the competitive level. In particular, following Harrington $(2004 \mathrm{a}, 2004 \mathrm{~b})$ cartels may try to stay on a higher price path after cartel breakdown by implementing some forms of tacit collusion. This results in an overestimation of the but-for price and a corresponding underestimation of the overcharge. Our overcharge estimates are therefore conservative and should provide lower bounds of the real overcharge.

${ }^{22}$ Variables that refer to the period of collusion are marked with $C P$ (cartelperiod). At this stage the given statistics are not representative since panel participation varies over time. The descriptive statistics of all $C P$ variables must therefore be interpreted with caution. For the overcharge estimation, however, this is negligible as long as purchase acts are randomly drawn.
} 
The shares of purchase acts during collusion are 19, 12 and 1 percent for cartel, retailer and manufacturer brands, respectively. Hence, 32 percent of all purchase acts in the dataset occurred during collusion, which is consistent with the 9 out of 24 months of the observation period.

29 percent of all detergents were sold in at least one form of promotion, that is, a price-flag, feature, handbill or display. As for most observations those different activities occur simultaneously, we combine them in the variable "Promotion" and control for it in our regressions. In 7 percent of the transactions the detergents were sold with a give-away and we therefore further include the binary variable "Gimmick".

Regarding product characteristics, 62 percent of the purchase acts concern concentrated and 34 percent color detergent. Sensitive detergents by contrast merely represent 3 percent of the data. In concentrated detergents the effective amount of detergent is higher, which in turn leads to a higher price. With respect to the type of packaging, most detergents are bought in refill bags (54 percent), followed by boxes (33 percent) and carry packs (13 percent). We use boxes as reference package type in our estimations.

The average per kilogram price of powdered laundry detergent is 1.98 Euro. The per kilogram price varies considerably between 60 cents for the cheapest and 6.33 Euro for the most expensive product. The average package size of detergents in our dataset is 2.97 kilogram. As Figure 1 reveals, the average per kilogram price does not linearly decline in package size but over-proportionally. In order to see whether this nonlinear pattern is still observable if we account for different product characteristics, we include both the package size and its square as independent variables in our model.

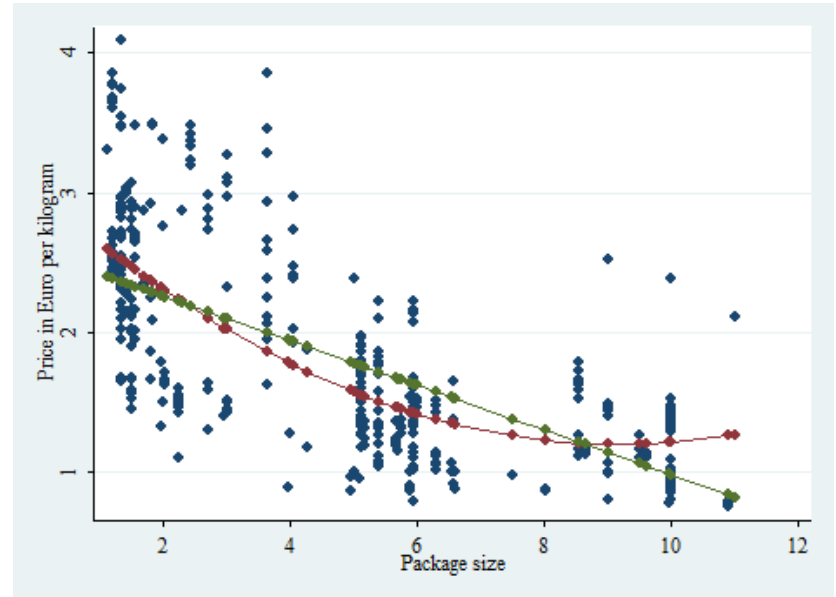

Figure 1: Price vs. package size; linear and quadratic fit

Table 2 summarizes price statistics for the cartel products as well as for manufacturer and retailer 
brands during and outside the cartel period. ${ }^{23}$ These numbers must be interpreted with care, as the price statistics do not take product differentiation and changes in costs into account. In general, cartel products are the most expensive ones, followed by retailer and manufacturer brands. For cartel brands, both average and median per kilogram prices are slightly higher during the period of collusion. By contrast, the mean prices of retailer and manufacturer products are lower during the cartel period. However, whereas the price reduction of retailer brands is negligible, manufacturer brands are considerably cheaper during collusion. This is at least partly due to the fact that input costs distinctly decreased during the cartel period and increased afterwards, thereby reducing production costs for all (cartel and non-cartel) detergent producers.

Table 2: Price statistics (in $€ / \mathrm{kg}$ ) during cartel and non-cartel period

\begin{tabular}{lccccc}
\hline Price & Mean & Median & Std. dev. & Min & Max \\
\hline \hline Cartel Brands (NCP) & 2.28 & 2.41 & 0.85 & 0.64 & 6.32 \\
Cartel Brands (CP) & 2.33 & 2.46 & 0.87 & 0.67 & 5.91 \\
Manufacturer Brands (NCP) & 1.45 & 1.03 & 0.76 & 0.61 & 3.70 \\
Manufacturer Brands (CP) & 1.34 & 0.85 & 0.83 & 0.60 & 3.79 \\
Retailer Brands (NCP) & 1.55 & 1.55 & 0.23 & 0.60 & 3.76 \\
Retailer Brands (CP) & 1.54 & 1.60 & 0.19 & 0.76 & 2.43 \\
\hline All & 1.98 & 1.62 & 0.78 & 0.60 & 6.33 \\
\hline
\end{tabular}

\section{Overcharge estimation and consumer damage}

\subsection{Estimation methods}

The most challenging issue in the quantification of cartel damages lies in the identification of a suitable counterfactual situation describing how the market outcome would have evolved in a competitive environment. Econometric damage estimation mainly follows either the so called "before and after", the "yardstick" or the "difference-in-differences" approach. ${ }^{24}$ The former method compares for the same market pre- and/or post cartel prices to the prices paid by purchasers during collusion. It is assumed that the competitive situation in the market during the cartel would have been similar to the situation before and/or after collusion. Regressing the price of the concerned product on a binary variable for the cartel period and a number of control variables allows to determine the average cartel induced price increase during collusion and thus the identification of a suitable benchmark price. The damage is then calculated as difference between the observed cartel price and the corresponding but-for price, multiplied by the quantity of the product sold in the cartel period. ${ }^{25}$ By contrast, the yardstick method uses data on the cartelized market and specific yardstick markets that are comparable to the cartel market in terms of demand and cost

\footnotetext{
${ }^{23}$ Variables that refer to the non-collusive period are marked with $N C P$ (non-cartel period).

${ }^{24}$ See Oxera, 2009.

${ }^{25}$ See Davis and Garcés, 2010.
} 
factors as well as product characteristics, but not affected by cartelization. That is, one uses for instance the same product market in other countries as benchmark for the same time period.

The difference-in-differences approach combines the two formerly described methods. It compares the price changes of the cartel products with benchmark products during and outside the cartel period in order to identify anti-competitive price deviations. Following Oxera (2009), the basic idea of this approach can be described as follows:

Figure 2: Difference-in-differences method

\begin{tabular}{l|c|c|c}
\hline & Non-cartel period & Cartel period & Overcharge estimation \\
\hline Cartel firms & $\mathrm{A}$ & $\mathrm{B}$ & \multirow{2}{*}{$(B-A)-(D-C)$} \\
\hline Non-cartel firms & $\mathrm{C}$ & $\mathrm{D}$ & \\
\hline
\end{tabular}

Let $\mathrm{A}$ and $\mathrm{B}$ be the average prices charged by the cartel firms outside and during the cartel period for the cartel product, and $\mathrm{C}$ and $\mathrm{D}$ the average prices charged by non-cartel firms for the same product outside and during the cartel period. In our case for instance, we use price data of powdered laundry detergent from the three cartel firms as well as from various other non-cartel firms. The difference (B-A) then captures the price change of the cartelized product between cartel and non-cartel period. As this difference may not be completely driven by the cartel but at least partly due to other factors, the difference (D-C) is used as benchmark. It reflects the price change of the same product produced by non-cartel firms between both periods of time. As both cartel and non-cartel firms should be confronted with the same market and input cost variations over time, the difference in the differences (B-A)-(D-C) should separate those factors and capture the cartel caused price increase..$^{26}$

In the following we will estimate a before-and-after model not only for cartel brands but separately for all three groups of brands. This allows us to identify whether retailer brands and/or competitive manufacturer brands are suitable reference categories for a subsequent difference-indifferences estimation. Precisely, since it can be expected that non-cartel firms react to the price increases by the cartel firms via own price increases (umbrella pricing) or price reductions (in order to encourage the redirection of demand from cartel brands to own products), both possible reference categories can only be used if we do not observe - after having controlled for all relevant price drivers - a significant price reaction for these products during the collusive period.

\subsection{Before-and-after approach: implementation and results}

We implement the before-and-after approach in a reduced-form or "hedonic" framework by estimating the following fixed effects panel data model:

\footnotetext{
${ }^{26}$ This approach is based on the assumption that cartel and non-cartel firms react similarly to demand, supply and market changes in terms of adaptions in their product prices.
} 


$$
\log \left(p_{i t}\right)=\beta_{0}+\beta_{1}^{\prime} \text { Characteristics }_{i}+\beta_{2}^{\prime} \text { Cost }_{t}+\beta_{3}^{\prime} \text { Retail }_{i t}+\beta_{4} \text { Cartel }_{t}+\varepsilon_{i t} .
$$

In all our estimations the dependent variable is the logarithm of the price for one kilogram heavyduty detergent of a specific product type $i$ at time $t .{ }^{27}$ We use the price per quantity instead of the full package price because we observe even for the same brand up to five different package sizes during the observation period. Thus, using the price per quantity makes products more comparable and eases interpretation. We also decided to use the logarithm instead of the absolute value of the kilogram price as it allows to measure relative effects of the independent variables. When thinking about retailer margins, the retailer would rather add an amount relative to the wholesale price instead of a fix sum; the same applies for discounts.

We explain the price differences of detergents by their characteristics, cost development over time, the conduct of the retailers and the effect of the upstream cartel. ${ }^{28}$

\section{Cross-sectional product characteristics}

In principle, one could measure the effect of the cartel for each product code we observe. However, as most product codes are not available for the whole observation period ${ }^{29}$ and in order to make products more comparable, we abstract from product codes in favor of underlying product characteristics, which are likely to explain price differences across product codes. It should be noted that the reduced form approach can not separate whether the characteristics' effect on price stem from the demand or the supply side as we only observe the net effect. Included characteristics are indicator variables for color, sensitive and concentrated detergents, respectively. We additionally include binary variables for the type of packaging as measures for packaging costs. Furthermore, it is controlled for package size and its square, as it can be observed that smaller packages are sold at an over-proportionally higher per kilogram price; this can coevally be explained by price discrimination of second degree and economies of scale. We additionally include fixed effects for the brands. They reflect the fact that brands might have a different popularity due to differing advertising intensities. In addition, the fixed effects allow for different margins of the manufacturers as well as differences in production and marketing costs.

\footnotetext{
${ }^{27}$ Note that at this point we estimate separate models for cartel, retailer and competitive manufacturer brands. Different product types therefore refer to the same main brand but differentiate with respect to package size, package type as well as further product characteristics (e.g. color, sensitive and concentrated detergents).

${ }^{28}$ It is worth noting that we do not explicitly control for demand drivers in our regressions. As the consumption of washing powder is relatively stable per household and over time, we do not expect the overall demand to change fundamentally in the long term. In the short term however, consumers might be sensitive with respect to price changes and special offers. Those substitution effects nevertheless primarily occur between products that are similarly perceived by consumers, which should coincide with our brand categorization.

${ }^{29}$ There are several reasons for this. First, we only have price data of products the representative sample of consumers bought. Beyond that, it frequently happens that producers exchange the varieties of their products.
} 


\section{Time-varying factors}

To control for non-cartel induced price differences over time, we use six cost measures which reflect input and production costs for the detergent producers. These are monthly price indices for palm oil, raps oil, rock phosphate, industrial power, chemical base materials and retail prices which we obtained from the German Statistical Office and the platform Index Mundi. ${ }^{30}$ As the detergents are not produced at the same day they are sold, we include the logarithm of all of these variables lagged by one month.

\section{Retailers conduct}

Considering the retailers conduct, we account for different retailer margins and costs by including indicator variables for each of the 15 biggest chains represented in our dataset. We take Lidl as reference chain as consumers can find both manufacturer and retailer brands there. We do not interact the chain fixed effects with the cartel period indicator variable as we do not expect retailer margins and costs to change due to the upstream cartel. ${ }^{31}$ For retailer brands, we set all chain indicator variables to zero. One reason for this is a technicality. As most retailers only sell one retailer brand in the detergent category, we would have perfect collinearity with the brand fixed effects. Furthermore, one can conceptually argue that there is only one margin which is already accounted for by the brand fixed effect.

Some products were occasionally promoted via price tags, features and handbills or separately displayed. We therefore include another dummy variable for those product specific advertising efforts ("Promotion"). Last but not least, we include the binary variable "Gimmick" which is equal to one if a product was sold with a give-away.

\section{Cartel effect}

To measure the overcharge caused by the cartel we include the binary variable Cartel $_{t}$, which is equal to one during the cartel period and zero otherwise. The estimated coefficient of this variable captures the average percentage price change during the cartel period compared to the competitive phase.

Table 3 summarizes the results of before-and-after fixed effects estimation ${ }^{32}$ for all three

\footnotetext{
${ }^{30}$ Index Mundi collects detailed country statistics, charts, and maps compiled from multiple sources, see http://www.indexmundi.com .

${ }^{31}$ The inclusion of the interactions results in insignificant coefficients for all terms. Testing for joint significance also results in favor of the null hypotheses of no joint significance.

${ }^{32} \mathrm{We}$ also estimated the model without fixed effects, i.e. Pooled OLS. Omitting fixed effects biases the overcharge estimate as there is a cartel-independent heterogeneity among brand prices. This even becomes more crucial in the difference-in-differences setting. Standard errors also differ significantly in the Pooled OLS case, indicating substantial heteroscedasticity and serial correlation of the error terms. Hence, robust and clustered standard errors are mandatory for correct inference.
} 
groups of brands. ${ }^{33}$ The indicator variables for concentrated, color and sensitive detergent do not significantly influence the logarithm of the per kilogram price of cartel products. By contrast, we find significant higher prices of sensitive retailer brands $(32.7 \%)$ and concentrated competitive manufacturer brands $(23.6 \%)$. With respect to the package size, we see the expected non-linear pattern for all three groups of brands. Furthermore, whereas the type of packaging does not seem to influence the relative prices of cartel and competitive manufacturer brands, retailer brands sold in bags are significantly higher priced than in boxes (7.36\%). In addition, on average promotional activities decrease the per kilogram prices by $10.6 \%$ (cartel and comp. man. brands) and $1.40 \%$ (retailer brands), respectively. Cartel products sold with gimmicks do not show a significantly different price than products without gimmicks, however, competitive manufacturer detergents sold with gimmicks are significantly lower priced. ${ }^{34}$

Table 3: Before-and-after estimation results

\begin{tabular}{|c|c|c|c|c|c|c|}
\hline \multirow{2}{*}{$\begin{array}{l}\text { Variable } \\
\text { Concentrated }\end{array}$} & \multicolumn{2}{|c|}{ Cartel brands } & \multicolumn{2}{|c|}{ Retailer brands } & \multicolumn{2}{|c|}{ Comp. man. brands } \\
\hline & 0.073 & $(0.065)$ & 0.006 & $(0.013)$ & $0.212^{* * *}$ & $(0.026)$ \\
\hline Color & 0.008 & $(0.008)$ & -0.015 & $(0.016)$ & -0.003 & $(0.010)$ \\
\hline Sensitive & -0.001 & $(0.008)$ & $0.283^{* * *}$ & $(0.024)$ & -0.004 & $(0.032)$ \\
\hline Package size & $-0.178^{* * *}$ & $(0.016)$ & $-0.175^{* * *}$ & $(0.048)$ & $-0.260 * * *$ & $(0.009)$ \\
\hline Package size(sq) & $0.009 * * *$ & $(0.001)$ & $0.010^{*}$ & $(0.005)$ & $0.014^{* * *}$ & $(0.001)$ \\
\hline Packaging: Bag & 0.033 & $(0.029)$ & $0.071^{* * *}$ & $(0.012)$ & & \\
\hline Packaging: Carry Pack & -0.031 & $(0.017)$ & -0.001 & $(0.055)$ & 0.068 & $(0.013)$ \\
\hline Gimmick & -0.026 & $(0.020)$ & & & $-0.056^{* * *}$ & $(0.018)$ \\
\hline Promotion & $-0.112^{* * *}$ & $(0.008)$ & $-0.014^{*}$ & $(0.007)$ & $-0.112^{* * *}$ & $(0.010)$ \\
\hline Chem. base mat. (L1) & 0.150 & $(0.259)$ & $-0.664^{* * *}$ & $(0.086)$ & $-1.616^{* * *}$ & $(0.309)$ \\
\hline Retail prices (L1) & $1.244^{* *}$ & $(0.515)$ & $1.853^{* * *}$ & $(0.324)$ & $7.085^{* * *}$ & $(2.013)$ \\
\hline Industrial power (L1) & $1.190^{* *}$ & $(0.447)$ & $0.560^{* * *}$ & $(0.125)$ & $2.291^{* * *}$ & $(0.679)$ \\
\hline Palmoil (L1) & $0.289 * * *$ & $(0.048)$ & $0.181^{* * *}$ & $(0.035)$ & 0.143 & $(0.169)$ \\
\hline Rapsoil (L1) & 0.019 & $(0.051)$ & $0.129 * * *$ & $(0.014)$ & -0.118 & $(0.075)$ \\
\hline Rock Phosphate (L1) & $-0.135^{*}$ & $(0.065)$ & $-0.250^{* * *}$ & $(0.047)$ & -0.283 & $(0.323)$ \\
\hline Cartel period & $0.065 * * *$ & $(0.010)$ & $0.026^{* * *}$ & $(0.005)$ & 0.027 & $(0.023)$ \\
\hline Constant & $-12.027^{* * *}$ & $(2.979)$ & $-8.338^{* * *}$ & $(0.866)$ & $-33.682^{* * *}$ & $(7.875)$ \\
\hline Chains & \multicolumn{2}{|c|}{ Yes } & \multicolumn{2}{|c|}{ No } & \multicolumn{2}{|c|}{ Yes } \\
\hline Brands & \multicolumn{2}{|c|}{ Yes } & \multicolumn{2}{|c|}{ Yes } & \multicolumn{2}{|c|}{ Yes } \\
\hline Observations & \multirow{2}{*}{\multicolumn{2}{|c|}{$\begin{array}{c}20.352 \\
0.80\end{array}$}} & \multirow{2}{*}{\multicolumn{2}{|c|}{$\begin{array}{c}13.813 \\
0.57\end{array}$}} & \multicolumn{2}{|c|}{1.060} \\
\hline$A d j . R^{2}$ & & & & & & \\
\hline
\end{tabular}

*** Significant at $1 \%,{ }^{* *}$ Significant at $5 \%, *$ Significant at $10 \%$ level

Robust and clustered std. errors (among brands) reported in parentheses

Turning to the mean effect of the cartel on prices, we find significant positive overcharges for cartel and retailer brands, but no significant price increase for competitive manufacturer brands during the period of collusion. On average, cartel products are $6.72 \%$ higher priced during the collusive period than in the competitive state after cartel breakdown. The overcharge of retailer brands $(2.63 \%)$ additionally indicates that retailers indeed reacted to price changes by the market leaders via own price adjustments, leading to significant umbrella effects during collusion. Hence,

\footnotetext{
${ }^{33}$ As our dependent variable is transformed by the logarithm function, the (percentage) marginal effects must be calculated as the exponentiated coefficients minus one (not reported in the table).

${ }^{34}$ Our data do not contain retailer brand products that were sold with gimmicks.
} 
using retailer brands as control group for difference-in-differences estimations would result in an underestimation of the true damage. However, apart from the fact that competitive manufacturers did not react to elevated cartel prices with own price changes, there are several other reasons why they constitute a more appropriate benchmark group than retailers. Firstly, the price setting of cartel brands and competitive manufacturer brands is comparable since in both product groups, producer margins as well as retailer margins are imposed, whereas retailer brand products merely include a retailer margin. Secondly, cartel brands and manufacturer brands are promoted similarly as the producing firms do costly national advertising in order to build up a certain image. Private retailer brands by contrast are commissioned by the retailers via subcontracts and do not get advertised in public media. Finally, while private retailer brands are only sold in the corresponding stores they are produced for, both cartel brands and competitive manufacturer brands are generally offered in all kinds of shops. Due to these aspects as well as the fact that we do not observe a significant overcharge of competitive manufacturer brands, we use them as product counterfactual in the subsequent difference-in-differences estimation. This additionally provides a robustness check with respect to our results. A large deviation in the results between both approaches would either indicate that the before-and-after model is flawed due to missing explanatory variables, or that the benchmark brands in the difference-in-differences estimation do not constitute an appropriate product counterfactual. ${ }^{35}$ On the other hand, if both approaches reveal similar cartel overcharges we can conclude that the before-and-after model is already sufficiently specified and accounts for all relevant price drivers. In particular, it implies that there are no substantial unobserved effects a reference product group can control for and we might have omitted in the before-and-after estimation.

\subsection{Difference-in-differences approach: implementation and results}

In order to implement the difference-in-differences estimation we extend our before-and-after model from the previous section by the interaction term cartel_brands ${ }^{*}$ cartel_period. It captures the price increase of cartel firms during the period of collusion compared to the price development of our benchmark brands (competitive manufacturers). Precisely, the estimated coefficient of the underlying interaction term corresponds to the above mentioned price difference in the differences of cartel and competitive manufacturer brands during and outside the cartel period. Table 4 summarizes the results.

The estimation reveals no general significant price change between the collusive and the competitive period. However, relative to the reference group of manufacturer brands who capture

\footnotetext{
${ }^{35}$ Conversely, this is equivalent to saying that either the before-and-after model is correctly specified, i.e. accounts for all relevant price drivers, or that the difference-in-differences model preforms better as the benchmark brands add significant explanatory power with respect to the price variation over time.
} 
the competitive pricing behavior over time, we find a significant overcharge of $6.93 \%$ for cartel brands, which is close to the $6.72 \%$ overcharge from the previous before-and-after estimation. We can therefore conclude that our before-and-after model is already sufficiently specified in the sense that competitive manufacturer brands do not add additional explanatory power to the development of per kilogram prices over time.

Table 4: Difference-in-differences estimation results

\begin{tabular}{|c|c|c|}
\hline Variable & Ref. group: & Man. brands \\
\hline Concentrated & 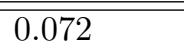 & $\overline{(0.063)}$ \\
\hline Color & 0.007 & $(0.007)$ \\
\hline Sensitive & -0.003 & $(0.007)$ \\
\hline Package size & $-0.183^{* * *}$ & $(0.016)$ \\
\hline Package size(sq) & $0.009^{* * *}$ & $(0.001)$ \\
\hline Packaging: Bag & 0.030 & $(0.028)$ \\
\hline Packaging: Carry Pack & -0.026 & $(0.016)$ \\
\hline Gimmick & -0.025 & $(0.019)$ \\
\hline Promotion & $-0.113^{* * *}$ & $(0.008)$ \\
\hline Chem. base mat. (L1) & 0.074 & $(0.245)$ \\
\hline Industrial power (L1) & $1.230^{* *}$ & $(0.397)$ \\
\hline Retail prices (L1) & $1.639 * *$ & $(0.565)$ \\
\hline Palmoil (L1) & $0.276^{* * *}$ & $(0.045)$ \\
\hline Rapsoil (L1) & 0.011 & $(0.044)$ \\
\hline Rock Phosphate (L1) & $-0.121^{*}$ & $(0.059)$ \\
\hline Cartel period & -0.001 & $(0.037)$ \\
\hline Cartel_brands*cartel_period & $0.068 *$ & $(0.036)$ \\
\hline Constant & $-13.593^{* * *}$ & $(3.054)$ \\
\hline Chains & \multicolumn{2}{|c|}{ Yes } \\
\hline Brands & \multicolumn{2}{|c|}{ Yes } \\
\hline Observations & \multicolumn{2}{|c|}{21.412} \\
\hline$A d j . R^{2}$ & \multicolumn{2}{|c|}{0.80} \\
\hline
\end{tabular}

\subsection{Quantification of consumer damages}

Given the overcharge estimates of the before-and-after estimation from the previous section we now turn to the quantification of the consumer harm. Since each cartelist offers numerous products of washing powder that differ regarding package type and size (and therefore also with respect to the per kilogram price), we first calculate the absolute overcharge for each single product type individually. However, as the dependent variable is in logarithm we cannot directly multiply the estimated coefficients by the paid price but rather have to run an auxiliary regression to get a consistent adjustment factor. ${ }^{36}$ In order to extrapolate the damages for the entire German population, we weight each purchase act by the representativeness of the buying household. For

\footnotetext{
${ }^{36}$ Following Jensen's inequality the expected logarithm of price and the logarithm of the expected price do not coincide $(E(\log (p)) \neq \log (E(p)))$. We therefore have to predict $\log (p)$ using the estimated model, calculate the exponential of it and use it as explanatory variable for a regression on the real price itself, without a constant. The calculated adjustment factors for the cartel and retailer regressions are 1.0274 and 1.0038, respectively. See Wooldridge (2003) for further information on this approach.
} 
this purpose, we use scaling factors that were provided along with the dataset. ${ }^{37}$

Since our previous estimations revealed that the retailers reacted to the price increase of the market leaders via price adjustments of their own detergent products, we additionally calculate the monetary effect of this umbrella pricing. Table 5 summarizes the respective results.

Table 5: Consumer harm and umbrella effect between July 2004 and March 2005

\begin{tabular}{l|r|r}
\hline & Cartel damage & Umbrella effect \\
\hline \hline Overcharge (\%) & 6.72 & 2.63 \\
\hline Damage (Mio. $€$ ) & 13.210 & 1.738 \\
\hline Turnover in CP (Mio. $€$ ) & 183.471 & 63.693 \\
\hline Damage as \% of CP Turnover & 7.20 & 2.73 \\
\hline
\end{tabular}

Our results suggest that the overall monetary consumer damage caused by the three cartel firms in the relevant product category between July 2004 and March 2005 amounts to 13.210 million Euro. Compared to the turnover generated by the cartel firms during this period in the respective product category, the damage corresponds to $7.20 \%$ of turnover.

If we assume that both cartel pricing and consumer behavior during these last nine months of collusion are representative for the entire cartel period, the overall damage suffered over the entire cartel period from January 2002 until March 2005 even amounts to 55.775 million Euro.

It is important to note that this calculated damage solely refers to the German detergent market. According to the EC eight further European markets such as France, Spain or Italy were affected by the cartel. Following the decision document of the EC, the total annual cartel member sales in the eight affected countries sum up to about 1.385 billion Euros for the relevant category. ${ }^{38}$ Calculating $7.20 \%$ for 38 months would then result in an overall consumer damage of 315.78 million Euro. $^{39}$ Interestingly, this number is pretty close to the 315.2 million Euro fine imposed by the EC in 2011.

Turning to the umbrella pricing we quantify this effect to 1.738 million Euro for the last nine months of the cartel agreement. Under the assumption that the reaction of the retailers during this period is representative for the entire cartel duration, the umbrella effect amounts to 7.34 million Euro. Although not directly caused by the cartel firms this harm leads to an additional decrease in consumer welfare, raising the overall monetary damage for consumers in Germany to a total of 63.115 million Euro.

\footnotetext{
${ }^{37}$ Unfortunately, the original scaling factors provided by Nielsen were related to only one point in time. Due to the high number of panel entries and exits of households over time we could not use them directly. However, owing to the high accuracy of the scaling factors and using information on panel entry and exit dates, we could recalculate adjusted factors on a weekly basis. In total, the recalculated scaling factors sum up to 39.11 Mio., which coincides with the number of German households during the years 2004 and 2005.

${ }^{38}$ Supra n. 6.

${ }^{39}$ This assumption is obviously critically and would not hold before court. However, we make this assumption in order to illustrate the dimension of consumer damages due to a cartel. In practice one would nevertheless have to use data for all affected markets as well as the entire cartel period in order to quantify the exact overall damage.
} 


\section{Conclusion}

Motivated by the current discussion whether special procedures for bringing collective actions to protect consumer interests should be available in the EU, we showed in this paper how consumer panel data can be used in order to estimate overcharges and to quantify consumer damages from price-fixing agreements. Our estimations for the European detergent cartel suggest average overcharges between 6.7 and 6.9 percent and an overall consumer damage of 13.2 million Euro in Germany over the period from July 2004 until March 2005. Under the assumptions that the pricing behavior of cartelists and buying behavior of consumers during the last nine months of cartelization are representative for the entire cartel period, the overall consumer damage even accounts for about 55.7 million Euro. If we further assume that the estimate is relevant for all affected markets, we observe an overall damage of about 315 million Euro.

Although our results indicate that it is straightforward to quantify consumer damages, several obstacles for consumer associations in order to implement our approach in practice still remain. Firstly, on EU level there is no clear authorization for such organizations to claim consumer damages so far. The implementation of such a regulation however would not only enable consumer associations to actively fulfill their mandate of consumer protection, but would even contribute to increased cartel deterrence, since the fact that any individual or entity can claim damages hampers the possibility for cartels to ex-ante predict the financial success of a potential cartel agreement. Precisely, without effective private enforcement firms can use the EU Guidelines on the method of setting fines in which the calculation of fines is described in detail in order to ex-ante approximate the success of a potential cartel participation. With private enforcement on the other hand, it is almost impossible to predict who is going to claim damages in case of cartel detection and what the overall fine will be at the end. Hence, although it is ambiguous whether this undermines existing leniency programs ${ }^{40}$, such an uncertainty should generally reduce firms' enthusiasm regarding cartel participation and thereby increase deterrence.

Secondly, it is essential for claimants to get access to evidence. Apart from general case information - which in the detergent case is rather scarce - it is particularly important to have the opportunity to gather relevant data that can be used for damage estimations. Whereas consumer panel data are easy to obtain from firms who are specialized in collecting scanner data, wholesale prices are usually impossible to get without the help of public authorities. The availability of consumer panel data along with wholesale data however would allow for a more in-depth analysis of consumer damages. In particular, one could compare the overcharges on retailer and final consumer layer and thus analyze passing-on effects and the distribution of harm between the different

\footnotetext{
${ }^{40}$ One way for ruling this out would be to exclude whistleblowers from private enforcement. This could even increase the incentives to apply for leniency and thereby reduce cartel stability.
} 
layers more accurately.

Last but not least, since the incentive for every single consumer to claim damage is relatively low due to the small individual loss, it is necessary to provide a practical system that effectively allows to bundle individual claims. It is doubtful whether an opt-in procedure as proposed by the European Commission is sufficient or whether on an opt-out redress system is the preferred option. As noted by the European consumer consultative group, recent experience in Europe showed that the rate of consumer participation of the opt-in procedure is extremely low (less than 1 percent) in comparison to an opt-out regime (between 97 and 100 percent). ${ }^{41}$ The latter would therefore certainly increase incentives to sue and therefore facilitate consumer organizations to represent consumers interests.

\footnotetext{
${ }^{41}$ Id at 4.
} 


\section{References}

[1] Basso, L. J., Ross, T. W. (2010): Measuring the true harm from price-fixing to both direct and indirect purchasers. The Journal of Industrial Economics, 58(4), pp. 895-927.

[2] Bueren, E., Smuda, F. (2013): A Primer on Damages of Cartel Suppliers - Determinants, Standing US vs. EU and Econometric Estimation. ZEW Discussion Paper 13-063, Mannheim.

[3] Bien, F. (2013): Perspektiven für eine europäische Gruppenklage bei Kartellverstößen? - Die Opt out-Class Actions als Äquivalent der Vorteilsabschöpfung, Neue Zeitschrift für Kartellrecht, 1/2013, pp. 12-17.

[4] Boone, J., Müller, W. (2012): The distribution of harm in price-fixing cases. International Journal of Industrial Organization, 30 (2012), pp. 265-276.

[5] Davis, P., Garcés, E. (2010): Quantitative Techniques for Competition and Antitrust Analysis. Princeton.

[6] European Commission (2011): EC press release IP/11/473, 13/04/2011. Commission fines producers of washing powder $€ 315.2$ million in cartel settlement case.

[7] European Commission (2011): Commission decision Case Comp/39579 - Consumer detergents.

[8] European Commission (2005): Green Paper Damages actions for breach of the EC antitrust rules, $\operatorname{SEC}(2005)$ 1732. Downloadable at http://eurlex.europa.eu/LexUriServ/LexUriServ.do?uri=CELEX:52005DC0672:EN:NOT .

[9] European Commission (2008): White Paper on Damages actions for breach of the EC antitrust rules, $\operatorname{SEC}(2008)$ 404-406. Downloadable at http://eurlex.europa.eu/LexUriServ/LexUriServ.do?uri=CELEX:52008DC0165:EN:NOT .

[10] European consumer consultative group (2010): Opinion on private damages actions. Downloadable at http://ec.europa.eu/consumers/empowerment/docs/ECCG_opinion_on_ actions_for_damages_18112010.pdf .

[11] Han, M. A., Schinkel, M. P., Tuinstra, J. (2008): The Overcharge as a Measure for Antitrust Damages. Amsterdam Center for Law \& Economics Working Paper 8.

[12] Harrington, J.E. (2004a): Post-Cartel Pricing during Litigation. Journal of Industrial Economics 52, pp. 517-533.

[13] Harrington, J.E. (2004b): Cartel Pricing Dynamics in the Presence of an Antitrust Authority. RAND Journal of Economics 35, pp. 652-674. 
[14] Kosicki, G., Cahill, M. B. (2006): Economics of cost pass through and damages in indirect purchaser antitrust cases. Antitrust Bulletin 51, pp. 599-630.

[15] Oxera (2009): Quantifying Antitrust Damages: Towards Non-binding Guidance for Courts, Study prepared for the European Commission.

[16] Van Dijk, T., Verboven, F. (2008): Quantification of Damages, in 3 Issues in Competition Law and Policy 2331 (ABA Section of Antitrust Law 2008), chapter 93.

[17] Verboven, F., Van Dijk, T. (2009): Cartel damages claims and the passing-on defense. The Journal of Industrial Economics, 57(3), pp. 457-491.

[18] Wooldridge, J. M. (2003): Introductory Econometrics: A Modern Approach. second edition, Thomson South-Western. 